\title{
Penggunaan Aplikasi Schoology dalam Pembelajaran Ditinjau dari Motivasi Belajar Mahasiswa (Studi Empiris pada Mahasiswa POR UMS)
}

\author{
Eko Sudarmanto $^{1 *}$, Nurhidayat ${ }^{1}$, Gatot Jariono ${ }^{1}$, Ardhian Tomy Kurniawan ${ }^{1}$, \\ Maimunah Nur Anisa ${ }^{1}$ \\ ${ }^{1}$ Fakultas Keguruan dan IImu Pendidikan, Universitas Muhammadiyah Surakarta, Indonesia \\ *Korespondensi: es348@ums.ac.id
}

\begin{tabular}{c}
\hline Info Artikel \\
\hline Diterima 26 Juli \\
2021 \\
Disetujui 15 \\
Agustus 2021 \\
Dipublikasikan 19 \\
Agustus 2021 \\
\hline
\end{tabular}

Keywords:

Schoology,

Motivasi Belajar, POR UMS

(C) 2021 The Author(s): This is an open-access article distributed under the terms of

the Creative

Commons

Attribution

ShareAlike (CC BYSA 4.0)

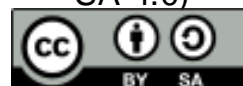

\section{Abstrak}

Tujuan peneslitian ini adalah untuk mengetahui penggunaan aplikasi schoology dalam pembelajaran ditinjau dari motivasi belajar pada mahasiswa POR UMS. Populasi dalam penelitian ini adalah mahasiswa Program Studi Pendidikan Olahraga Universitas Muhammadiyah Surakarta angkatan 2017-2021. Sampel yang digunakan dalam penelitian ini sebanyak 200 mahasiwa,Instrumen penelitian terdiri dari observasi, angket, dan wawancara, sedangkan untuk teknik pengambilan sampel penelitian menggunakan systematic random sampling dengan jenis pengambilan acak sistematis.. Teknik pengumpulan data dengan menggunakan observasi, angket dan wawancara sedangkan jenis penelitian ini adalah penelitian deskriptif kuantitatif dengan menganalisis data-data yang telah dikumpulkan kemudian dideskripsikan.Hasil penelitian ini menunjukkan bahwa penggunaan media aplikasi schoology dalam proses pembelajaran membantu mahasiswa meningkatkan motivasi dalam belajar dengan perolehan presentase rata-rata penggunaan aplikasi schoology sebesar $81,5 \%$ kategori mudah, sedangkan presentase hasil rata-rata motivasi belajar sebesar 63,5\% kategori setuju. Sehingga dapat disimpulkan bahwa dengan perolehan hasil presentase yang signifikan antara penggunaan aplikasi schoology dan motivasi belajar terdapat adanya peningkatan motivasi belajar pada mahasiswa POR UMS dengan menggunakan aplikasi schoology dalam proses pembelajaran berlangsung.

\section{Abstract}

The purpose of this study was to determine the use of Schoology applications in learning in terms of learning motivation in POR UMS students. The population in this study were students of the Sports Education Study Program, University of Muhammadiyah Surakarta, class of 2017-2021. The sample used in this study was 200 students. The research instrument consisted of observation, questionnaires, and interviews, while the research sampling technique used systematic random sampling with systematic random sampling. Data collection techniques used observation, questionnaires, and interviews while the type of This research is a quantitative descriptive study by analyzing the data that has been collected and then described. The results of this study indicate that the use of Schoology application media in the learning process helps students increase motivation in learning with the acquisition of an average 
percentage of Schoology application usage of $81.5 \%$ category easy, while the percentage of the average results of learning motivation of $63.5 \%$ category agree. So it can be concluded that with the acquisition of a significant percentage between the use of the Schoology application and learning motivation, there is an increase in learning motivation in POR UMS students by using the Schoology application in the learning process.

\section{Pendahuluan}

Pembelajaran merupakan proses interaksi antara peserta didik dengan pendidik, dan sumber belajar dari tingkat usia dini hingga perguruan tinggi. Salah satu tujuan pembelajaran yaitu pembelajaran efektif dan efisien. Untuk mencapai tujuan tersebut, harus didukung berbagai factor salah satunya adalah motivasi belajar, sarana dan prasarana, factor lingkungan social, dan yang terkait dengan tujuan pembelajaran yang direncanakan oleh pendidik. Mencermati permaslahan tersebut, terdapat kendala dalam situasi saat ini yaitu pandemi covid_19 yang melanda suluruh dunia. Situasi seperti saat ini diperlukan pembelajaran berbasis online salah satunya melalui Schoology. Schoology merupakan salah satu layanan gratis menggunakan konsep manajemen pembelajaran sosial untuk membangun semangat pembelajaran secara online yang aman untuk berbagi informasi.

Schoology digunakan sebagai alternatif pembelajaran secara online diberikan kemahasiswa di bebagai Perguruan Tinggi. Salah satunya adalah Program studi Pendidikan Olahraga Universitas Muhammadiyah Surakarta (POR UMS) mulai dari mahasiswa semester awal hingga semester akhir menggunakan aplikasi schoology dalam proses pembelajaran e-leraning. Begitupun dengan dosen POR UMS memanfaatkan aplikasi tersebut sebagai solusi penyampaian pembelajaran yang telah dikemas sedemikian rupa sehingga diharapkan mahasiswa POR UMS mudah untuk memahami, aktif, dan menambah motivasi belajar.

Penggunaan aplikasi schoology diharapkan mampu meningkatkan motivasi belajar mahasiswa POR UMS. Motivasi belajar merupakan dorongan yang muncul dari dalam diri peserta didik (intrinsik) dan begitupun dari luar diri peserta didik (ekstrinsik) untuk melakukan sesuatu. Motivasi ekstrinsik merupakan suatu dorongan yang berasal dari luar diri seseorang untuk mencapai suatu tujuan. Sedangkan motivasi intrinsik meliputi keinginan dan hasrat untuk berhasil, dorongan untuk memiliki kebutuhan belajar, dan harapan akan meraih cita-cita. Seperti yang diungkapkan oleh Gunarsa di dalam sebuah artikel (Nur Khasanah; Khomsum Nurhalim, 2016) motivasi intrinsik adalah sebuah dorongan atau keingianan yang kuat yang bersumber dari dalam diri seseorang. Apabila motivasi intrisnik yang dimiliki semakin kuat maka akan semakin besar peluang kemungkinan memperlihatkan tingkah laku yang kuat untuk mencapai tujuan. Sedangkan menurut Djamarah (2011) di dalam artikel (Balqis et al., 2014) motivasi intrinstik merupakan motif-motif yang tidak memerlukan rangsangan dari luar, karena setiap individu memiliki dorongan untuk melakukan sesuatu.

Terkait dengan belajar secara online menggunakan salah satu layanan manajemen sistem schoology sebagai alternatif pembelajaran jarak jauh yang diperintahkan oleh pemerintah dalam situasi pandemic covid-19. Schoology merupakan salah satu platform inovatif yang terinspirasi dari facebook yang 
dibangun untuk Pendidikan, dibuat di New York pada tahun 2009 dalam artikel (Achmad Sulaiman \& Chendra Wibawa, 2018). Schoology sebuah system manajemen pembelajaran yang memungkinkan untuk melakukan kolaborasi online antara siswa dan siswa, antara siswa dan guru bahkan orangtua (Haniah; Asminiwaty, Noor; Sihombing, 2019).

Pembelajaran online terdapat beberapa permasalahan yang timbul salah satunya terkait motivasi belajar peserta didik. Hal ini sejalan dengan beberapa hasil penelitian tentang motivasi belajar yaitu (Iskandar, 2018; Nanang Mulyana, 2017; Tigowati et al., 2017) suatu daya penggerak yang timbul baik dari dalam maupun dari luar diri seseorang yang menimbulkan keinginan belajar, untuk menjamin kelangsungan dari kegiatan belajar kearah proses kegiatan belajar, sehingga tujuan yang dikehendaki dapat tercapai.

Pada dasarnya motivasi belajar merupakan dorongan baik dari dalam maupun dari dalam diri individu untuk mengembangkan kemampuanya. Hal ini sesuai dengan amanah undang-undang nomor 20 tahun 2003 tentang sistem Pendidikan nasional yaitu "Pendidikan adalah usaha sadar dan terencana untuk mewujudkan suasana belajar dan proses pembelajaran agar peserta didik secara aktif mengembangkan potensi dirinya untuk memiliki kekuatan spiritual keagamaan, pengendalian diri, kepribadian, kecerdasan, akhlak mulia, serta keterampilan yang diperlukan dirinya, masyarakat, bangsa dan negara" (Depdiknas, 2003).

Amanah undang-undang tersirat bahwa tujuan dari pembelajaran salah satunya adalah pembelajaran secara efektif dan efesien agar peserta didik memiliki kepribadian, kecerdasan, dan aklak mulia sebagai modal untuk menghadapi dunia kerja. Seperti yang dijelaskan Pramuaji (2017) pembelajaran dapat diartikan sebagai upaya guru mengorganisir lingkungan dan menyediakan fasilitas belajar bagi peserta didik untuk mempelajarinya. Pada era sekarang ini hampir semua jenjang pendidikan menggunakan fasilitas sistem electronic learning yang ada. Menurut Rusman segala aktivitas belajar yang menggunakan bantuan teknologi elektronik disebut dengan e-learning. Perkembangan teknologi informasi sudah berkembangan dengan pesat, misalnya Lembaga System Management (LSM) (Situmorang, 2016).

Berdasarkan fonomena berupa fakta tersebut, peneliti tertarik untuk melakukan penelitian dengan judul "Penggunaan Aplikasi Schoology Dalam Pembelajaran Ditinjau Dari Motivasi Belajar (Studi Empiris Pada Mahasiswa POR UMS)".

\section{Metode Penelitian}

Penelitian ini menggunakan metode deskriptif kuantitatif merupakan salah satu jenis penelitian yang terencana, terstruktur, dan sistematis. Menurut Sugiy ono (2013:13) dalam artikel (Diantari \& Ulupui, 2016) metode penelitian kuantitatif adalah metode yang berlandaskan filsafat positivism, digunakan meneliti popu lasi dan sampel tertentu, teknik pengambilan sempel secara random. Populasi dalam penelitian ini adalah mahasiswa Program Studi Pendidikan Olahraga Universitas Muhammadiyah Surakarta angkatan 2017-2021. Sampel yang digunakan dalam penelitian ini sebanyak 200 mahasiwa, pengumpulan data menggunakan angket dan wawancara sebagai instrument penelitian, analisis data bersifat statistik dengan tujuan menguji hipotesis yang ditetapkan. 
a. Bentuk penelitian ini deskriptif digunakan untuk menganalisis penggunaan aplikasi schoology dalam pembelajaran ditinjau dari motivasi belajar mahasiswa. Teknik pengumpulan data berupa hasil observasi, angket, dan wawancara, sedangkan untuk menganalisa penelitian ini melalui 4 tahap yaitu:

b. Pengumpulan data, dengan melakukan observasi, angket, dan wawancara, untuk angket tentang penggunaan schoology dalam pembelajaran ditinjau da ri motivasi belajar mahasiswa dapat diakses melalui link: https://docs.google.com/forms/d/e/1FAlpQLSfd7mjC6Z8KUpoctRhjCy8PLzo4J mm69MbT3OiKX0vsi-ObKA/viewform?usp=sf link

c. Reduksi data, menggolongkan dan membuang data yang tidak perlu, dan mengorganisasikan data hingga diperoleh kesimpulan akhir.

d. Penyajian data, mengelompokkan data dengan menggunakan label.

e. Penarikan kesimpulan dari hasil data yang telah diolah baik secara kualitatif dan kuantitatif. Data yang telah dianalisis, kemudian diolah dalam bentuk presentase, lalu dideskripsikan dan didukung oleh penelitian sebelumnya.

\section{Hasil}

Hasil penelitian ini terkait dengan pembelajaran penggunaan aplikasi schoology dalam pembelajaran ditinjau dari motivasi belajar mahasiswa Pendidikan Olaharaga Universitas Muhammadiyah Surakarta dapat diuraikan sebagai berikut:

\subsection{Penggunaan schoology dalam proses pembelajaran pada masa pandemic}

Hasil analisis deskriptif frekuensi tentang penggunaan schoology dalam proses pembelajaran pada masa pandemic memaksimalkan menggunakan learning management system (LSM) untuk menunjang proses pembelajaran lebih berkualitas dan tetap berjalan sesuai dengan kurikulum yang berlaku pada program studi Pendidikan Olahraga Universitas Muhammadiyah Surakarta. Adapun sub indicator dari penggunaan aplikasi schoology yaitu kendala dan kemudahan penggunaan aplikasi schoology dengan pernyataan mudah dan tidak mudah, dapat dilihat pada histogram berikut;

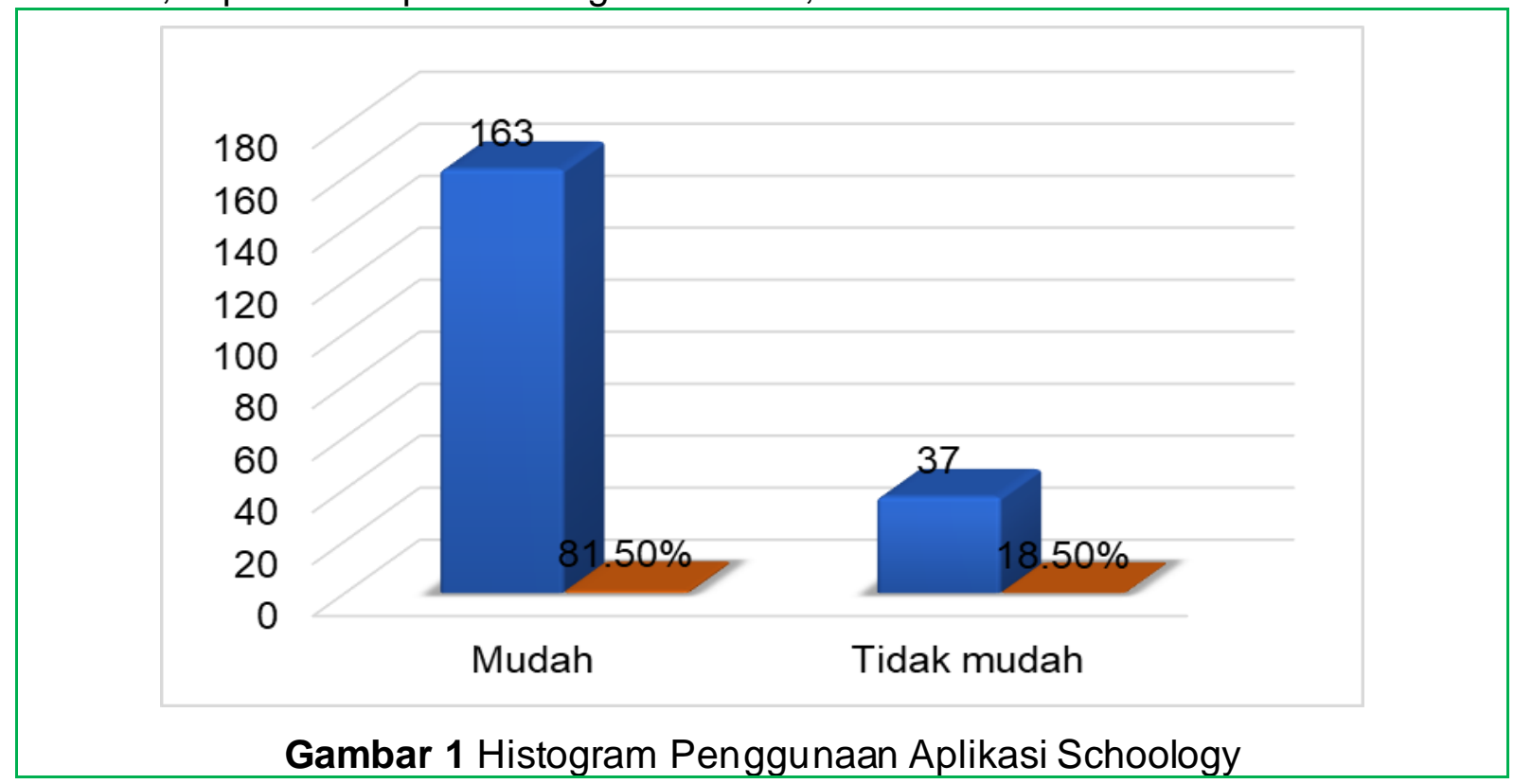


Berdasarkan diagram di atas dapat diketahui bahwa penggunaan aplikasi Schoology adalah mudah dengan frekuensi atau persentase terbesar yaitu 163 mahasiswa atau $81,5 \%$. Sementara itu, penggunaan aplikasi Schoology dengan kategori kategori tidak 37 mahasiswa atau 18,5, kategori kurang setuju 30 mahasiswa atau $13,64 \%$, kategori tidak setuju 0 mahasiswa atau $0 \%$, dan kategori sangat tidak setuju 0 mahasiswa atau $0 \%$. Selanjutnya hasil analisis deskriptif presentasi motivasi belajar mahasiswa dapat diuraikan berikut;

\subsection{Hasil motivasi belajar}

Hasil analisis presentase motivasi belajar mahasiswa terdiri dari indicator motivasi intrinsik dan ekstrinsik. Untuk sub indicator motivasi instrinsik yaitu adanya dorongan untuk menyelesaikan tugas tepat waktu, keinginan untuk berprestasi, memiliki harapan dan cita-cita, berusaha untuk lebih unggul dari oran $g$ lain sedangkan untuk motivasi ekstrinsik yaitu ingin memperoleh pengahargaan sesuai kemampuan yang dimiliki, ingin memperoleh pujian/pengakuan dari atasan atau teman dari apa yang dikerjakan, belajar dengan giat dengan harapan ingin memperoleh hasil yang lebih baik, dengan pernyataan sangat setuju, setuju, kurang setuju, tidak setuju, dan sangat tidak setuju. Adapun hasil dari analisis deskriptif presentase dapat dilihat pada gambar berikut:

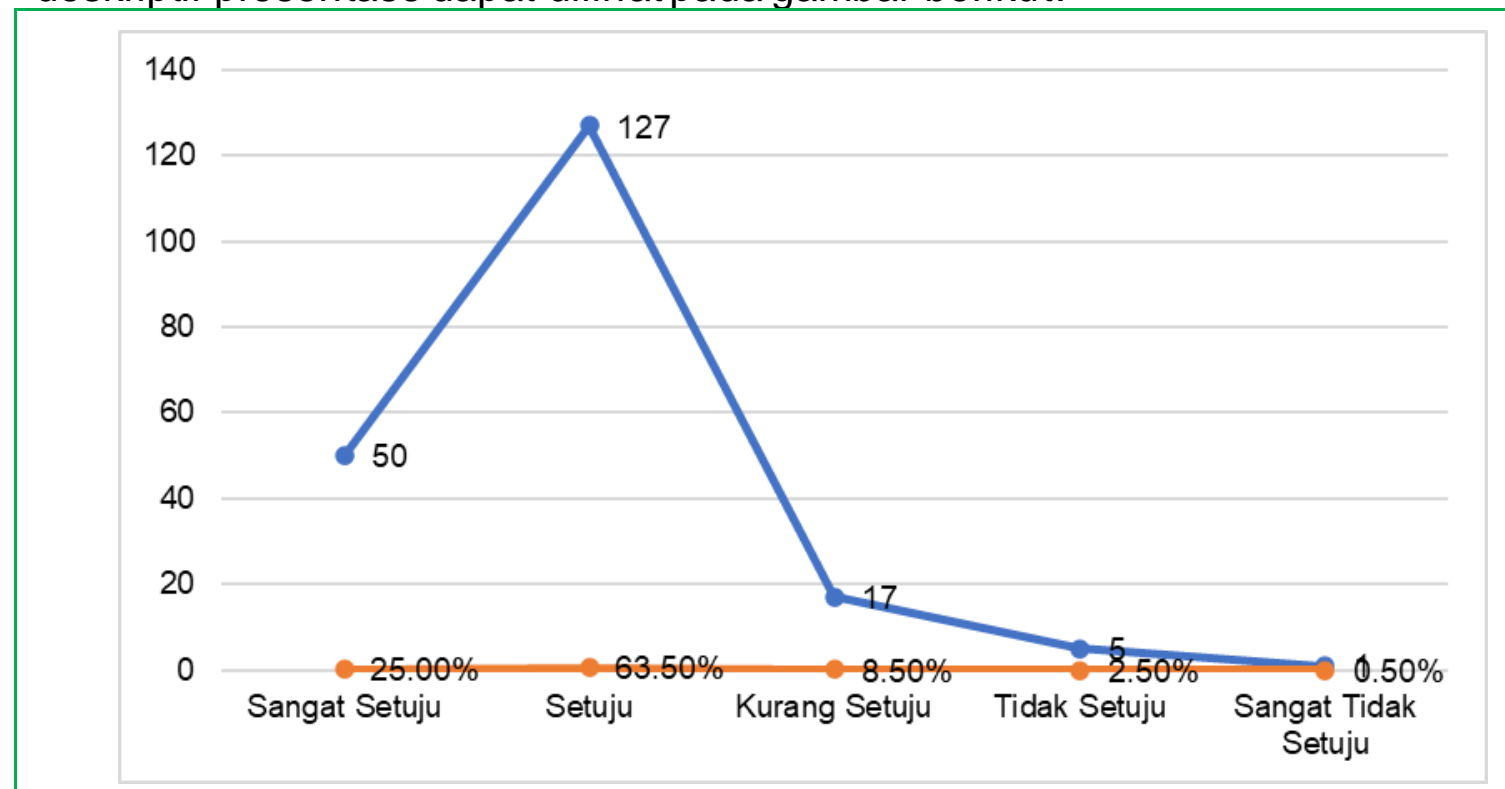

Gambar 2 Diagram Hasil Motivasi Belajar

Berdasarkan diagram di atas dapat diketahui bahwa motivasi belajar mahasiswa POR UMS dengan kategori Setuju dengan frekuensi atau persentase terbesar yaitu 127 mahasiswa atau 63,5\%. Sementara itu, motivasi belajar mahasiswa POR UMS dengan kategori sangat setuju 15 mahasiswa atau 25\%, kategori kurang setuju 17 mahasiswa atau 8,5\%, kategori tidak setuju 5 mahasiswa atau 2,5\%, dan kategori sangat tidak setuju 1 siswa atau $0.5 \%$. Uniknya dalam motivasi belajar terdapat $0.5 \%$ atau terdapat 1 orang mahasiswa tidak setuju dengan motivasi belajar pada masa pandemic covid_19 kemungkinan salah satunya adalah mahasiswa merasa bosan,stress, dan jenuh mengikuti perkuliahan secara daring serta jaringan internet kadang kurang bersahabat. 


\section{Pembahasan}

Berdasarkan hasil yang diperoleh dapat disimpulkan bahwa penggunaan aplikasi schoology menunjukkan kategori Setuju lebih dominan yakni dengan jumlah frekuensi atau presentase sebesar $76,82 \%$ atau 169 mahasiswa. Hasil tersebut menunjukkan bahwa dengan menggunakan aplikasi schoology dapat membantu proses pembelajaran pada mahasiswa POR UMS. Hal tersebut dikarenakan kemudahan saat mengakses aplikasi tersebut, tidak memerlukan kuota yang banyak, memudahkan mahasiswa dalam pengumpulan tugas, dan fitu $\mathrm{r}$ dalam aplikasi schoology mudah dipahami dan cukup lengkap sehingga mahasiswa setuju apabila aplikasi schoology digunakan sebagai salah satu media pembelajaran supaya kegiatan belajar mengajar dapat berjalan secara maksimal. Berdasarkan hasil tersebut didukung oleh yang dilakukan oleh Waginah Dwi Nuryaningsih (2021) yang menyatakan bahwa rata-rata penggunaan aplikasi schoology sangat tinggi dibandingkan dengan menggunakan aplikasi yang lainnya dilihat dari aspek kualitas dalam media pembelajaran dan hasil belajar.

Kelebihan penggunaan aplikasi schoology salah satunya adalah memudahkan mahasiswa untuk mengerjakan tugas secara bersama sesuai dengan batas waktu pengu mpulan tugas yang diberikan oleh dosen. Namun dalam penggunaan shoology terdapat beberapa kelemahan yaitu jaringan internet lokasi mahasiswa domisili kadang kurang bersahabat dan diskusi secara tatap muka terkendala dengan jarak tempuh. Sedangkan kelebihan tanpa menggunakan schoology yaitu pengajar dapat berinteraksi secara langsung kepada peserta didik untuk menjelaskan secara mendetail dalam perkuliahan.

Keberhasilan proses pembelajaran dapat dipengaruhi oleh kondisi psikologis mahasiswa, seperti berapa besar motivasi yang dimiliki mahasiswa untuk meningkatkan hasil belajar dan kesadaran akan pentingnya belajar. Motivasi belajar merupakan suatu dorongan dari dalam maupun luar diri seseorang untuk melakukan sesuatu agar tercapainya tujuan tersebut. Beberapa hasil peneltian tentang motivasi belajar yaitu (Albrecht \& Karabenick, 2018; Filgona et al., 2020; Rafiola et al., 2020; Tran, 2019; Zheng et al., 2020) "motivasi merupakan suatu perubahan energi yang ada di dalam diri seseorang yang ditandai dengan munculnya afektif (perasaan) dan reaksi untuk mencapai tujuan."

Motivasi merupakan kekuatan pada diri seseorang sebagai pendorong u ntuk mewujudkan suatu prilaku dengan tujuan memuaskan dirinya (Oktiani, 2017). Sedangkan menurut Jariono \& Subekti (2020) motivasi merupakan perubahan energi yang ada di dalam maupun diluar diri seseorang yang menunjukan adanya reaksi untuk mencapai tujuan tertentu. Hasil tersebut didukung penelitian yang dilakukan oleh (Tigowati et al., 2017) dan penelitian dari (Waginah Dwi Nuryaningsih, 2021) motivasi merupakan kemauan untuk melakukan sesuatu aktivitas keseharian yang timbil dari dalam dan dari luar individu.

Dengan demikian timbulnya motivasi pada seseorang dapat ditandai dengan adanya suatu perubahan yang ada dalam diri seseorang yang dapat disadari atau tidak. Hal tersebut digambarkan oleh mahasiswa POR UMS dari hasil survei yang dilakukan bahwa motivasi belajar diperoleh kategori Setuju dengan presentase atau frekuensi sebesar $73,18 \%$ atau 161 mahasiswa.

Faktor intrinsik dan ekstrinsik merupakan hal penting dalam memotivasi mahasiswa agar lebih giat dalam melakukan belajar, sebagai dorongan untuk 
melakukan sesuatu guna mencapai tujuan. Motivasi belajar muncul dari dalam diri mahasiswa dan begitupun dari luar diri mahasiswa. Contohnya seperti adanya dorongan untuk menyelesaikan tugas tepat waktu, keinginan untuk berprestasi, memiliki harapan dan cita-cita, ingin memperoleh penghargaan sesuai kemampuan yang dimiliki, ingin memperoleh pujian dari orang lain, dan menjadikan belajar dengan giat dengan harapan ingin memperoleh hasil yang lebih baik.

Keberhasilan proses pembelajaran dapat dipengaruhi oleh kondisi psikologis mahasiswa, seperti berapa besar motivasi yang dimiliki mahasiswa untuk meningkatkan hasil belajar, dorongan untuk mencapai tujuan, dan kesadaran akan pentingnya belajar. Motivasi belajar merupakan suatu dorongan dari dalam (intrinsik) maupun luar (ekstrinsik) diri seseorang untuk melakukan sesuatu agar tercapainya tujuan tersebut. Sehingga adanya perubahan dalam diri individu untuk memperoleh hasil yang lebih baik.

Faktor intrinsik dan ekstrinsik merupakan hal penting dalam memotivasi mahasiswa agar lebih giat dalam melakukan belajar, sebagai dorongan untuk melakukan sesuatu guna mencapai tujuan. Motivasi belajar muncul dari dalam diri mahasiswa dan begitupun dari luar diri mahasiswa. Contohnya seperti adanya dorongan untuk menyelesaikan tugas tepat waktu, keinginan untuk berprestasi, memiliki harapan dan cita-cita, ingin memperoleh penghargaan sesuai kemampuan yang dimiliki, ingin memperoleh pujian dari orang lain, dan menjadikan belajar dengan giat dengan harapan ingin memperoleh hasil yang lebih baik.

Dengan demikian dapat disimpulkan bahwa pembelajaran menggunakan aplikasi schoology dapat meningkatkan motivasi belajar pada mahasiswa. Motivasi tersebut berdasarkan kelebihan aplikasi schoology sehingga mahasiswa terbantu dalam proses pembelajaran.

\section{Kesimpulan}

Berdasarkan hasil penelitian dapat disimpulkan bahwa penggunaan aplikasi schoology menunjukkan kategori Setuju lebih dominan yakni dengan jumlah frekuensi atau presentase sebesar $63,5 \%$ atau 127 mahasiswa. Hasil tersebut menunjukkan bahwa dengan menggunakan aplikasi schoology dapat membantu proses pembelajaran pada mahasiswa POR UMS. Hal tersebut dikarenakan kemudahan saat mengakses aplikasi tersebut, tidak memerlukan kuota yang banyak, memudahkan mahasiswa dalam pengumpulan tugas, dan fitur dalam aplikasi schoology mudah dipahami dan cukup lengkap sehingga mahasiswa setuju apabila aplikasi schoology digunakan sebagai salah satu media pembelajaran supaya kegiatan belajar mengajar dapat berjalan secara maksimal. Dengan demikian dapat disimpulkan bahwa pembelajaran menggunakan aplikasi schoology dapat meningkatkan motivasi belajar pada mahasiswa. Motivasi tersebut berdasarkan kelebihan aplikasi schoology sehingga mahasiswa terbantu dalam proses pembelajaran.

\section{Daftar Pustaka}

Achmad Sulaiman, P., \& Chendra Wibawa, S. (2018). Penerapan Media Pembelajaran Berbasis Schoology Mobile Untuk Meningkatkan Hasil Belajar Pada Mata Pelajaran Jaringan Dasar Kelas X Tkj Di Smk Pahlawan Mojosari. 
It-Edu, 3(01), 75-84.

Albrecht, J. R., \& Karabenick, S. A. (2018). Relevance for Learning and Motivation in Education. Journal of Experimental Education, 86(1), 1-10. https://doi.org/10.1080/00220973.2017.1380593

Balqis, P., Ibrahim, N., \& Ibrahim, S. (2014). Kompetensi Pedagogik Guru Dalam Meningkatkan Motivasi Belajar Siswa Pada Smpn 3 Ingin Jaya Kabupaten Aceh Besar. Jurnal Administrasi Pendidikan : Program Pascasarjana Unsyiah, 2(1), 25-38.

Depdiknas. (2003). Undang-Undang RI No 20 Tahun 2003. In Undang-Undang Republik Indonesia Nomor 20 Tahun 2003 Tentang Sistem Pendidikan Nasional Dengan Rahmat Tuhan Yang Maha Esa Presiden Republik Indonesia.

Diantari, P. R., \& Ulupui, I. A. (2016). Pengaruh Komite Audit, Proporsi Komisaris Independen, Dan Proporsi Kepemilikan Institusional Terhadap Tax Avoidance. E-Jurnal Akuntansi, 16(1), 702-732.

Filgona, J., Sakiyo, J., Gwany, D. M., \& Okoronka, A. U. (2020). Motivation in Learning. Asian Journal of Education and Social Studies, 10(4), 16-37. https://doi.org/10.9734/ajess/2020/v10i430273

Haniah; Asminiwaty, Noor; Sihombing, O. (2019). Panduan Pengembangan Pembelajaran Tata Busana Berbasis Teknologi Digital (Schoology) Untuk Instruktur. 1-45.

Iskandar, D. (2018). Implementasi Kompetensi Profesional Guru Dalam Meningkatkan Motivasi Belajar Peserta Didik. Journal of Management Review. https://doi.org/10.25157/jmr.v2i3.1804

Jariono, G., \& Subekti, N. (2020). Sports Motivation Survey And Physical Activity Students Of Sport Education Teacher Training And Education Faculty FKIP Muhammadiyah University Surakarta. Kinestetik: Jurnal IImiah Pendidikan Jasmani. https://doi.org/10.33369/jk.v4i2.12449

Nanang Mulyana. (2017). Upaya Meningkatkan Motivasi Belajar Dalam Aktivitas Perkuliahan Atletik Melalui Implementasi PAIKEM Nanang. JUARA : Jurnal Olahraga.

Nur Khasanah; Khomsum Nurhalim. (2016). Motivasi Orangtua Dalam Mengikuti Program Bina Keluarga Balita Di Kelurahan Uwung Jaya Kota Tangerang. Journal of Nonformal Education and Community Empowerment, 5(1), 9-15.

Oktiani, I. (2017). Kreatifitas Guru Dalam Memotivasi Belajar Peserta Didik. Http://Jurnalkependidikan.lainpurwokerto.Ac.ld Kreativitas, 5(2), 216-232.

Pramuaji, A. (2017). Pengembangan Media Pembelajaran Interaktif Pada Materi Pengenalan Corel Draw Sebagai Sarana. Jurnal Elektro, 2(3), 183-189.

Rafiola, R. H., Setyosari, P., Radjah, C. L., \& Ramli, M. (2020). The effect of learning motivation, self-efficacy, and blended learning on students' achievement in the industrial revolution 4.0. International Journal of Emerging Technologies in Learning, 15(8), 71-82. https://doi.org/10.3991/ijet.v15i08.12525 
Situmorang, A. S. (2016). Model Pembelajaran E-Learning Berbasis Web Terhadap Kemampuan Pemecahan Masalah Mahasiswa Prodi Pendidikan Matematika Fkip Universitas HKBP Nommensen T.A 2015/2016. JURNAL Suluh Pendidikan FKIP-UHN, 3(1), 15.

Tigowati, T., Efendi, A., \& Budiyanto, C. W. (2017). E-Learning Berbasis Schoology Dan Edmodo: Ditinjau Dari Motivasi Dan Hasil Belajar Siswa SMK. Elinvo (Electronics, Informatics, and Vocational Education). https://doi.org/10.21831/elinvo.v2i1.16416

Tran, V. D. (2019). Does cooperative learning increase students' motivation in learning? International Journal of Higher Education, 8(5), 12-20. https://doi.org/10.5430/ijhe.v8n5p12

Waginah Dwi Nuryaningsih. (2021). Penerapan Media Schoology untuk Meningkatkan Motivasi dan Hasil Belajar Siswa dalam Pembelajaran Bahasa Indonesia di SMP Negeri 3 Bojong Pekalongan. Jurnal Paedagogy, 8(1), 1623.

Zheng, L., Bhagat, K. K., Zhen, Y., \& Zhang, X. (2020). The effectiveness of the flipped classroom on students' learning achievement and learning motivation: A meta-analysis. Educational Technology and Society, 23(1), 1-15. 